Dieser Fall ist ein Beispiel für den bisher zahlreichsten Wurf bei Clethrionomys glareolus glareolus $\mathrm{S} \mathrm{ch} \mathrm{reb.} \mathrm{und} \mathrm{er} \mathrm{weist} \mathrm{gleichsam,} \mathrm{ahnlich} \mathrm{wie} \mathrm{bei}$ den Angaben von $\mathrm{Naumov}$ (9 Junge) auf die Möglichkeit des Auftretens von verhältnismässig zahlreichen Würfen hin, die weit von den Durchschnittlichen abweichen.

\title{
SCHRIFTTUM
}

(O g n ev, S. I.) Огнев C. H. - Звери ССCP и прилежащих стран, том VII: 50-51. АН ССCP, Москва-Ленинград, 1950. Steven, M. D. - The Bank Vole (Clethrionomys glareolus) (in "The UFAW Handbook on the Care and Management of Laboratory Animals", ed. by Worden, A. N. \&. Lane Petter, W.: 309-314) UFAW, London, 1957. W r a n g e l, H. Fr. von -- Beiträge zur Biologie der Rötelmaus, Clethrionomys glareolus S ch r e b. Ztschr. Säugetierk., Vol. 14: 52-93. Berlin, 1940.

Inst. für Säugetierforschung in Białowieża, Polnische Akad. der Wiss.

\section{Jerzy SIDOROWICZ}

CRANIAL MEASUREMENTS OF THE GARDEN DORMIOUSE (ELIOMYS QUERCINUS SUPERANS OG NEV \& STRAGA N O V, 1936) FROM EUROPEAN PART OF USSR

(ELIOMYS QUERCINUS SUPERANS OGNEV \& STRAG A N O V, 1936) Z EUROPEJSKIEJ CZĘSCI ZSRR.

Garden Dormouse is a species widely distributed in the whole Europe nearly. North Sea and Baltic Sea up to southern Finland are the northern borders of it's occurrence. Garden Dormouse occur up to Ural in the East (Van den B rin k, 1956).

Acoording to Ognev (1947) there are two subspecies in the Central Europe: Eliomys quercinus quercinus L. and Eliomys quercinus superans Ognev \& Stroganov. According to this author's opinion several described species of the genus Eliomys occuring in the Mediterranean region are only the geographical races of the species Eliomys quercinus L. There is an interesting fact, that Garden Dormice in areas placed farthest to the East and Westwards are the largest in size and they are separated by areas of occurrence of smaller race $-E$. q. quercinus. The border of distribution of $E$. q. quercinus and E. q. superans is not yet established. According to $\mathrm{O} g \mathrm{n}$ e v in Poland there is form "quercinus" and farther Eastwards form "superans".

In Poland Garden Dormouse can be found in Tatra Mts., Pieniny Mts., in Silesia and in Lublin region ( $\mathrm{S} \mathrm{k} \mathrm{u} \mathrm{r} \mathrm{a} \mathrm{tow} \mathrm{ic} \mathrm{z,} \mathrm{1947),} \mathrm{but} \mathrm{everywhere} \mathrm{in} \mathrm{a}$ very small number. In Polish collections I couldn't find any Garden Dormice suitable for comparison.

This report is based on the material of 37 dry specimens taken from the collection of the Zoological Museum of Lomonosov University in Moscov. 
I should like to express my hearty thanks to Professor Dr. W.G. Hept$\mathrm{n}$ e $\mathrm{r}$ for giving me the possibility to use these materials for my publication.

In all materials caught in summer or in autumn we can see distinctly two age groups - young specimens and adults. I suppose it is the typical feature for the all Muscardinidae (S id orowicz, 1958; 1959 a, b).

The skulls were measured according to the method described by $\mathrm{W}$ a s ilewski (1952). The age was defined according to the degree of the molars wear, acc. to the degree of ossification of the skull suttures and to the general skull size.

Table 1.

Cranial measurements of E. q. superans.

\begin{tabular}{|c|c|c|c|c|c|c|}
\hline \multirow{2}{*}{ Measurement } & \multicolumn{3}{|c|}{$Y \circ \cup N G$} & \multicolumn{3}{|c|}{$A D \cup L T S$} \\
\hline & min. & avg. & $\max$. & m1n. & avg. & $\max$. \\
\hline Condylobasal length & 24.8 & 28.73 & 29.9 & 30.2 & 31.92 & 33.8 \\
\hline Zygomat1c breadth & 15.7 & 17.28 & 18.8 & 18.2 & 18.87 & 21.1 \\
\hline Interorbital constriotion & 4.7 & 4.92 & 5.2 & 4.7 & 4.72 & 5.2 \\
\hline Diastema & 6.3 & 7.35 & 7.8 & 7.2 & 7.91 & 8.8 \\
\hline Basal length & 25.1 & 26.34 & 27.4 & 27.8 & 29.31 & 31.2 \\
\hline Palatine he1ght & 5.9 & 6.67 & 7.1 & 6.7 & 7.21 & 7.8 \\
\hline Occ1p1tal breadth & 14.4 & 15.07 & 15.4 & 15.4 & 16.13 & 17.0 \\
\hline Height of skull per bullae & 12.2 & 12.88 & 13.6 & 13.1 & 13.57 & 14.2 \\
\hline Depth of brain-case & 9.3 & 9.87 & 10.5 & 9.8 & 10.20 & 10.8 \\
\hline Maxillary tooth-row & 4.4 & 4.75 & 4.9 & 4.9 & 5.07 & 5.2 \\
\hline Wand1bular tooth-row & 4.7 & 4.93 & 5.1 & 4.8 & 5.04 & 5.4 \\
\hline Number of 1ndividuals & \multicolumn{3}{|c|}{19} & \multicolumn{3}{|c|}{18} \\
\hline
\end{tabular}

Generally one can say that the specimens which have condylobasal length smaller than $30,0 \mathrm{~mm}$. are the young specimens. But it relates only to the greater race - Eliomys quercinus superans. The matter of individual variation of skull of central - European Garden Dormouse is hitherto unexamined.

\section{REFERENCES}

B rink, F. H. van den - Die Säugetiere Europas. Paul Parey. HamburgBerlin, 1956. (O g n e v, S. I.) О г н ев, С. И. - Звери СССР п прилежащих стран. Том 5. АН СССР. Москва, 1947. Sidorowic z, J. - Some notes on the Edible Dormouse (Glis glis L.) in Poland Acta Theriol Vol. 2, 14: 292-295. Białowieża, 1958, S i d o r ow i c z, J. - The Forest Dormouse (Dryomys nitedula $\mathrm{P}$ a $11 \mathrm{a} \mathrm{s}$ ) in the Białowieża National Park. Ib., Vol. 3, 2: 17-27. Białowieża, 1959. Si or o wi cz, J. - Uber Morphologie und Biologie der Haselmaus (Muscardinus avellanarius L) in Polen. Ib., Vol. 3, 5: 75-91. Białowieża, 1959. S ku r a towic z, W. - Klucz do ozraczania krajowych zwierząt ssących. Księgarnia Akademicka: 3-68. Poznań, 1947. W asilewski, W. - Badania nad morfologią Clethrionomys glareolus glareolus S chre b. Ann. Univ. M. Curie-Skłodowska, Sect. C, Vol. 7, 3: 119--211. Lublin, 1952.

J. Sidorowicz, Warszawa 45, Marymoncka 34/10. 